digious energy that Aaron Wildavsky brought to his vocation, but does not capture his unforgettable style, a mixture of Brooklynese breeziness and ferocious focus, a taste for paradoxical asides and a talent for penetrating insight. There is also his amazing breadth. An envious colleague once doubted that Wildavsky ever had a thought that went unrecorded. We will never know whether that is true; what we do know is that of those thoughts he did record, a very great many have formed the agenda for his fellow political scientists. The subfield of implementation, for example, got a powerful jump start from Wildavsky's book of that name with Jeffrey Pressman. Likewise the resuscitation of the study of public budgeting as a branch of the study of the politics of public organization dates from Wildavsky's Politics of the Budgetary Process. Wildavsky's studies of Moses and of Joseph opened the Bible as a political science text. His book with Hugh Heclo, The Private Government of Public Money, is by common opinion among the handful of great works on British public administration. At the time of his death, he was exploring the scientific claims of American environmentalists and the administrative styles of the middle third of the American presidents, among other projects.

Aaron Wildavsky was born May 31, 1930, in Brooklyn, New York, the son of Eva and Sender Wildavsky, who had emigrated to the United States from Poltava, in the Ukraine, some dozen years earlier. He grew up in the Brownsville section of Brooklyn, graduating from New York's PS 89, Erasmus Hall High School, and Brooklyn College. He served in the U.S. Army and in 1954-55 had a Fulbright Fellowship to the University of Sydney. In 1955 he embarked on graduate work at Yale and by 1958 completed his dissertation, Dixon Yates: $A$ Study in Power Politics, written under the supervision of Allan P. Sindler. There ensued as remarkably productive a career as the political science profession has ever seen.

Wildavsky is survived by his wife, Mary, four adult children by his previous marriage to the late Carol Shirk: Adam, Sara, Ben, and Dan, and by a granddaughter, Eva Miriam
Wildavsky, born September 5, 1993 to Ben and Rachel Wildavsky. He is survived also by legions of friends in America and abroad, by numerous students, collaborators and colleagues to whom he and his neverending stream of ideas were a constant stimulus and, in some cases, an inspiration.

Nelson W. Polsby

University of California at Berkeley

\section{Rudolf Wildenmann}

Rudolf Wildenmann, a leading figure in post-war German political science, passed away on July 14 in his 72nd year. Professor Wildenmann was well-known and admired by his American colleagues for his frequent participation in our professional meetings and for his guest lectureships at several American universities. What is perhaps less well known here is just what an important role he had played in rebuilding and reshaping modern German political science. It is no exaggeration to say that during the post-war period he helped create and nurture the development of empirical political science, with special emphasis on political behavior; thereby giving the field a new direction.

To Americans he is perhaps best known for pioneering the systematic study of voting behavior, utilizing modern empirical methodology. His study of the 1961 German general election was an early landmark in that field. It is through his efforts that German television (Channel 2) instituted regular, systematic analyses of electoral behaviors as well as monthly observations of the public's civic attitudes. Rudolf Wildenmann also has to be credited with the founding of ZUMA, a unique academic research institute located in Mannheim which focuses on basic social science research and innovative social science methodology.

In addition Wildenmann worked widely on the conduct and role of political parties in various regimes. He wrote numerous articles and monographs on the subject and was the main editor of a series on the future of party government. Another interest of his was the study of political elites and the consequence of various elite strategies for the wellbeing of the polis. That important work, begun in 1968, was conceived and executed as a longitudinal enterprise with subsequent studies in 1974 and 1981. Just prior to his death he was making preparations for a follow-up study on East-West German elites after unification.

Rudolf Wildenmann received his Ph.D. in 1952 from the University of Heidelberg. After a career as journalist and public servant, he obtained his habilitation in 1959 at the University of Cologne. In 1964 he assumed a professorship in political science at the University of Mannheim, three times becoming its rector (1967, 1969, and 1976). Upon his retirement he founded the Research Unit for Societal Development to which he invited scholars from different countries and disciplines whom he encouraged to collaborate in research on crucial problems evident in modern industrial nations. These efforts, under his guidance and frequent editorship, resulted in the publication of sixteen volumes covering a great variety of topics, from ecology to economics to party governance, and many more. This ability to attract and encourage the collaboration of scholars from many places and different disciplines and to draw in younger colleagues was perhaps his greatest forte. It is to this skill and his tireless efforts (together with those of Stein Rokkan and Jean Blondel) that we owe the European Consortium for Political Research where every year young political scientists come together at varying European universities to work on a joint project.

To a large extent all his efforts were animated by his deep concern for the development and nurture of democracy in the post-war German republic-a concern reflected already in his habilitation publication Macht und Konsensus als Problem der Innen- und Aussenpolitik. He never lost sight of that concern. This September he was to participate on an APSA panel on the topic. We shall miss him.

Roberta S. Sigel Rutgers University 